\title{
Initial Reading Lesson through "Dia Tampan" Association Method and Android Photo Editor Media
}

\author{
Prana Dwija Iswara ${ }^{1,}$, J. Julia ${ }^{1}$, Tedi Supriyadi ${ }^{2}$, Aam Ali Rahman ${ }^{2}$, Tatat Hartati ${ }^{1}$, Rahman $^{1}$, \\ Wahyu Sopandi ${ }^{1}$, Vismaia S. Damaianti ${ }^{1}$
}

${ }^{1}$ Elementary Teacher Education, Universitas Pendidikan Indonesia, Indonesia

${ }^{2}$ Elementary Physical Education, Universitas Pendidikan Indonesia, Indonesia

Received March 3, 2020; Revised April 4, 2020; Accepted April 19, 2020

Copyright $\bigcirc 2020$ by authors, all rights reserved. Authors agree that this article remains permanently open access under the terms of the Creative Commons Attribution License 4.0 International License

\begin{abstract}
Technology, as an android smartphone, can be utilized in initial reading lesson. This research discussed the result of initial reading lesson through android photo editor in a smartphone. This research was initiated by numbers of unfinished learners in initial reading lesson. The aims of this research are (1) describing the steps of using photo editor as learning media; (2) discussing the students' responses toward the media; (3) analyzing students' competences in general in initial reading lesson. An individual initial reading test was employed to test their reading competency. The observation of the use of photo editor as a media and students' interest toward it was done. The photo editor media was utilized by editing photos and doodling them as part of the initial reading and writing lesson. Students became more interested in learning through photo editor. Based on the observation result, the level of enthusiasm for the lesson was high. Students' time span in listening to the lesson was also high. In addition, students are able to re-write teachers' words as part of learning process.
\end{abstract}

Keywords Initial Reading Lesson, Android Photo Editor, Association Method, Dia Tampan Method, Primary School

\section{Introduction}

This research is grounded by learning activities of initial reading lesson for students who are not able to finish initial reading. Some of the students find it very hard to identify letters even though they have learned initial reading for years. Students who have difficulty in initial reading lessons will have difficulty in other lessons. Meanwhile, media is used to create a joyful activity for them. If it is possible, teachers may use a visual media, and advance organizer in reading multimedia-based texts
[1], [2]. Android photo editor is utilized as a media for this research as the other research used iPad in the classroom for foreign language learning [3]. Besides that, another research discussed learning online reading comprehension [4]-[6]. Such research has potential to develop discussion tools, real-time audio-visual chat, personal knowledge construction and annotation tools. There are also other related studies about students' use of online annotation tool in an online reading environment [7]. The other discussed students' processing information from digital media and educational materials, as they are increasingly being interrupted by competing media and their surroundings [8].

This research revealed that some unfinished students tended to lose their self-esteem, for they felt that the lesson was too challenging due to difficulty to memorize form of letters. In some cases, students were able to write their own name, yet they could not read properly. They still found it is difficult to read words. It is believed that this difficulty appeared since the form of the words were rather new for them. As an example, if a letter "a" was given, the shape was not common for them. It results trouble for them to memorize its form. Hence, those who had learnt it before may easily memorize the words' form. To attract the audiences, visual displays are believed as the great media; they help the teacher to motivate students automatically with the content as well as teachers in teaching them, not to mention the struggling readers. For teachers, words are more difficult to recall than images. Further, images are easier to be in long-term memory as well as give students the opportunity to access their imagination and synthesize the information compared to words or concepts [9].

Furthermore, not only android photo editor was used for this research, but also the association method and "dia tampan" method were employed. This "dia tampan" method has been published in research. Starting from a 
blog [10] and book, this method gains its fame in form of uploaded video to YouTube [11] and also intellectual copyrighted product [12]. Except presented researches, some other researches related to this research topic have been done by experts. There is a research discussed teacher intervention, the Targeted Reading Intervention (TRI), in helping struggling readers, teachers use diagnostic strategies with struggling readers. It used the experimental and control group method. As a result, Experimental children achieved better gains in letter-word identification than control children [13].

Research on students' motivation was a part of research into reading lessons [14]. This research examines the effectiveness of a volitional strategy through metacognitive development. This research used the volitional strategy through metacognitive development to increase students' motivation. Volitions act is defined as a factor of self-regulation to preserve, promote, and direct oneself to an activity to achieve the goal. Volitional control is exercised through students' activities to control their own desires and impulses during learning. There is also another study of students motivation in reading [15].

There was also a study that examined a new screening tool (Get Ready to Read or GRTR) for assessing early reading skills. This GRTR was developed for early childhood educators seeking to identify a developmentally appropriate assessment tool to screen preschool children's progress in acquiring reading-related skills [16]. Another study monitored early first-grade reading progress. It compared the validity of progress monitoring slope of nonsense word fluency (NWF) and word identification fluency (WIF) [17]. Another study aimed to get a description of family wording condition and motivation toward students' skill to initiate reading [18]. Another study was about the effects of storybook read-aloud interventions for children at risk for reading difficulties ages 3 to $8[19]$.

There was a study about similarity sibling pairs from three family types (monozygotic twins, dizygotic twins, and unrelated adoptive siblings). The study included measures of letter and word identification, phonological awareness, phonological decoding, rapid automatized naming, and general cognitive ability. Shared environmental effects were moderate and significant. Shared environmental effects estimated in twins were generally similar in magnitude to adoptive sibling correlations, suggesting highly replicable estimates across different study designs. The study is about family literacy conditions and reading motivation. Similarity sibling pairs from three family types (monozygotic twins, dizygotic twins, and unrelated adoptive siblings) influenced the students' initial reading ability. The study included measures of the letter and word identification, phonological awareness, phonological decoding, rapid automatized naming, and general cognitive ability [20]. Another study was to examine the effectiveness of 3 different types of feedback cueing strategies used with children with reading and language delays during guided reading sessions. Three feedback strategies-graphophonemic (GP), meaning based, and mixed (a combination of phonemic and meaning cues)-were used [21].

In reading lessons, teachers have chosen an online reading resources for learning reading. The literature review indicated that students from the fifth to the eighth grades did not show adequate web searching, evaluation, and integration abilities. Some studies have demonstrated that the development of integration ability might depend on web searching and evaluation abilities. This study was focused on Chinese online reading teaching and learning [22]. Another research focused on examining the online magazine-based reading workshop model towards the improvement of fourth-grade students' reading comprehension skills. The research was about online magazine-based reading workshop model for fourth-grade students' reading comprehension skills [23].

\section{Method}

Qualitative method of research and development (R\&D) was employed for this research by following 4 steps (4D): Define, Design, Develop and Disseminate [24]. Define includes analyzing problems, learners assignments, concepts and objectives using field and library studies. Design includes selecting media, formatting the reading material, referencing and developing the media (Android photo editor). Develop includes developing lesson stages through expert validation for the media, materials, teachers, peer reviews, trials, giving pre-test and refurbish the product. Disseminate includes applying the media to the other schools and disseminates in a seminar or publish it to the International journal.

Reading test and observation were used to find the result for this research. The use of photo editor media and students' interest in the lesson were observed. To be more specific, students' motivation during the lesson was analyzed. Moreover, two main observations were prepared. First is an observation toward students' interest in photo editor media. For this observation, students' interest that is reflected by their act toward photo editor media is analyzed. Second is an observation toward initial reading lesson steps using photo editor. Those steps are reported after learning reflection. The reflection is in form of the test which is analyzed by using a qualitative method i.e. determine general student completeness. Nine students from different schools joined the initial reading program. Four college students were involved as volunteers. Those students took different learning time.

This research was held from March to November 2018. As it is stated in the method, this research used Thiagarajan 4D procedure. It worked with 10 sample students from 
Bandung, 22 students from Sumedang and 11 initial reading teacher volunteers (students of elementary school teachers program). It also employed peer reviewers to validate the media and learning material. Meanwhile, the android photo editor media may involve 32 students who have not been given any lesson about the material.

To start the research, the volunteers were given three weeks of training related to the media, and only qualified volunteers were chosen. They were supplied with the programme specifications; teaching material, dia tampan reading method, association method, and the usage of android photo editor for the initial reading lesson.

\section{Result and Discussion}

One of the research's aim is the steps of using Android photo editor as a media. Since this application is installed default to every android smartphone, so practitioners/teachers do not need to install the application to the phone. Further, teachers combine photo editor method with Initial Reading lesson technique by using the association method and "dia tampan" method.

\subsection{Defining Learning Objectives}

This research was developed through the application of a photo editor associated with the "dia tampan" method for initial reading during the class sessions. A black photo background is used to replace a blackboard to learn words. This method had been applied in the classroom as a pilot study. This finding is enriched by initial reading theories and media. Meanwhile, this research aimed to define one learning procedure for the initial reading lesson through a photo editor in Android. Besides, it helps primary teachers to solve initial reading lesson issues.

A survey revealed that many students find it difficult to finish their initial reading process. This survey is served as a result of interviewing five primary teachers and headmasters in some schools about their students' ability of initial reading. This interview aimed to allow the application of media for students who have difficulty in the initial reading. Teachers, generally, feel excited for the volunteers to solve the issues in their classroom. They also appreciate the use of photo editor media in the initial reading. This media can also be used to solve those students' issues.

Furthermore, class observation has also been done. This observation was given to unfinished students in the initial reading. This observation aimed to create a bond between the tutors and students, so tutors can help students to solve their initial reading problems. This research employed 32 participants. The participants were chosen based on the requirement. To apply the method, lesson plans are used to help the research works.

\subsubsection{Android Photo Editor Media Usage}

In Initial Reading and writing lesson, photo editor media is utilized, so the lesson does not conventionally use board, book, or notebook only. It is completed by more advance media that attract more students to learn. Meanwhile, the steps on how to use Android photo editor program are as follow.

1. Click the android photo icon to open the camera

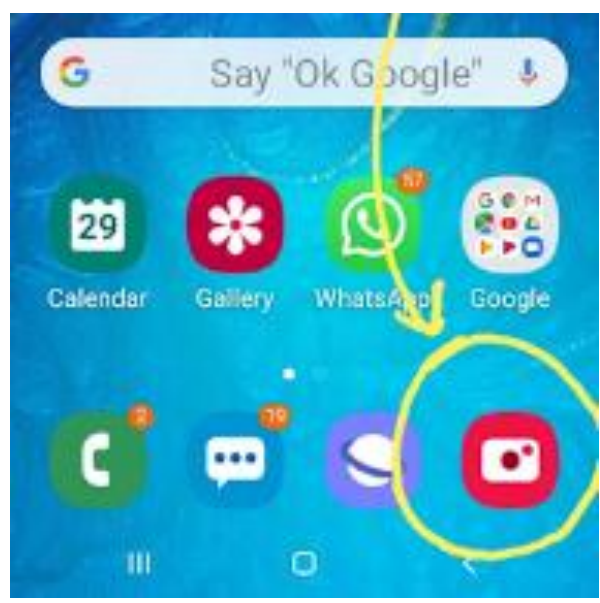

Figure 1. Open The Camera

2. Create a black blank photo by blocking the camera (use your hand), then open the unedited captured picture

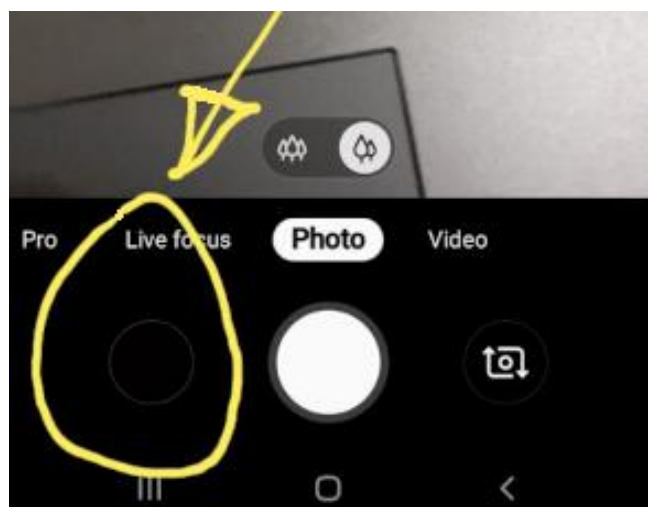

Figure 2. Create a Black Blank Photo

3. Click the pencil icon to edit the photo

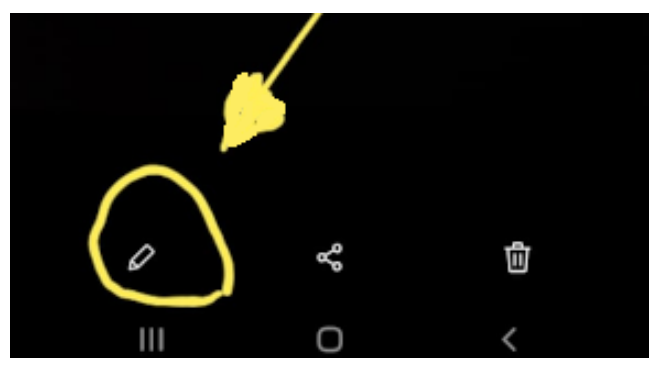

Figure 3. Edit The Photo 
4. Click doodle icon to choose the colour and to start writing

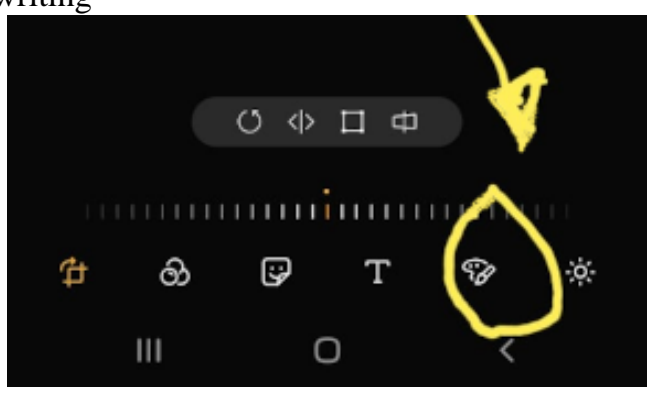

Figure 4. Click Doodle Icon

5. Start writing by using your finger on the previous black captured image

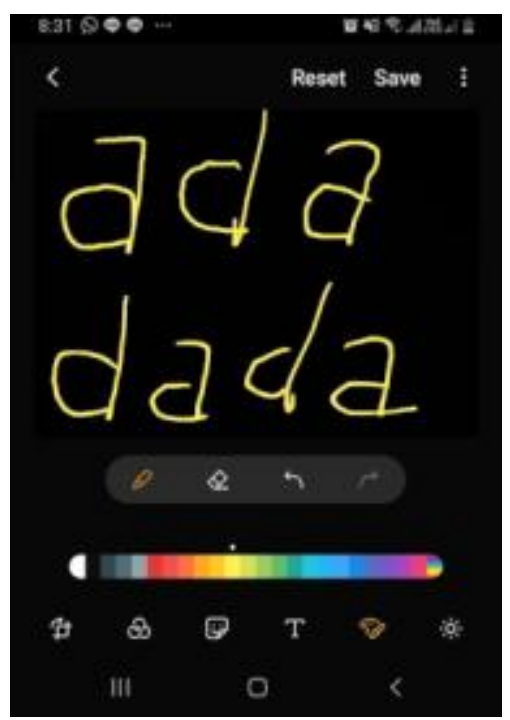

Figure 5. Start Writing

The picture below shows an example of how the method was applied (Figure 6).

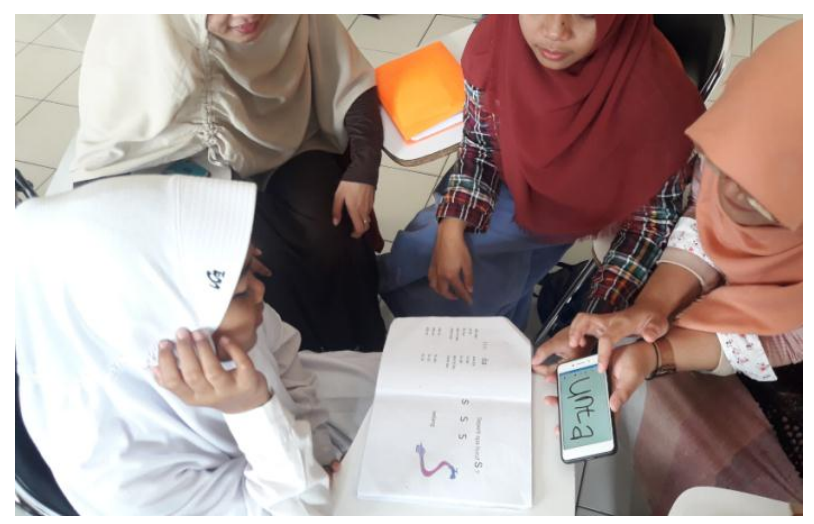

Figure 6. Teacher Shows the Media

The association method is used to help students to recognize the letters. As an example, a letter ' $d$ ' is associated with leaves or paddles, ' $n$ ' is for magnet or door, ' $\mathrm{t}$ ' is for door locks, ' $\mathrm{p}$ ' is for hammers, axes or knives, and ' $\mathrm{m}$ ' is for doves or tables. With this association method, it is hoped that students can easily recognize the letters. The use of photo editor as a media tends to ease the reading lesson for students. This media can also be an alternative to paper reading sources. Moreover, it can be used also as part of a writing lesson. So, students can write in a photo editor and can read teachers' writing from the media. In recent years some teacher use technologies in teaching [25], [26]. There has been a significant shift in methods of teaching and learning from computer-assisted learning into mobile-assisted learning.

\subsection{2. "Dia Tampan" Association Method}

"dia tampan" Association Method is a blended method from "dia tampan" and association learning method. In the association method, teachers associate the letters given to students with something familiar to them. For instance, the letter ' $a$ ' can be associated with apple, 'b' for bottle, bear or boy, and so on [27]. By associating letters with objects, students are expected to remember the shape of the letters more easily. This association method is used to introduce letters easier for students. Students who find it difficult to learn Initial Reading lesson are taught by 'dia tampan' association method along with android photo editor as the media. This association method must be applied by using the familiar thing students acknowledge, while 'dia tampan' is applied in Initial Reading lesson by using a similar consonant letter in a string of words[12].

In some cases, students who cannot complete the Initial Reading lesson are still advanced to the next level. As a result, more and more students of grade 2, 3, 4, 5 or 6 are not able to read properly. In some cases, even students from grade 6 still cannot fulfil Initial Reading lesson. Those students are subject to our participants for this research. Some hypotheses are appeared due to these issues. However, the difficulty factors are not discussed in this research. One of the hypotheses is that the cause of unfinished Initial Reading is that it is too late to introduce letters and pencils. As the result, they cannot recognize the letter as for 'a', 'i', 'u', 'e', 'o', and it is difficult for them to memorize the letters.

\subsubsection{Initial Reading Tasks}

The 'dia tampan' method uses letters 'd', 'n', 't', 'p', 'm' to repeat the keywords like ada 'there is', ini 'this is', itu 'that is', apa 'what ...', mana 'where ...'. To find out students' ability in Initial Reading, students are given an oral test. They are asked to read the task one by one to show their competence. The task given is step by step as part of 'dia tampan' method of learning. The task is seen as the following pictures. 


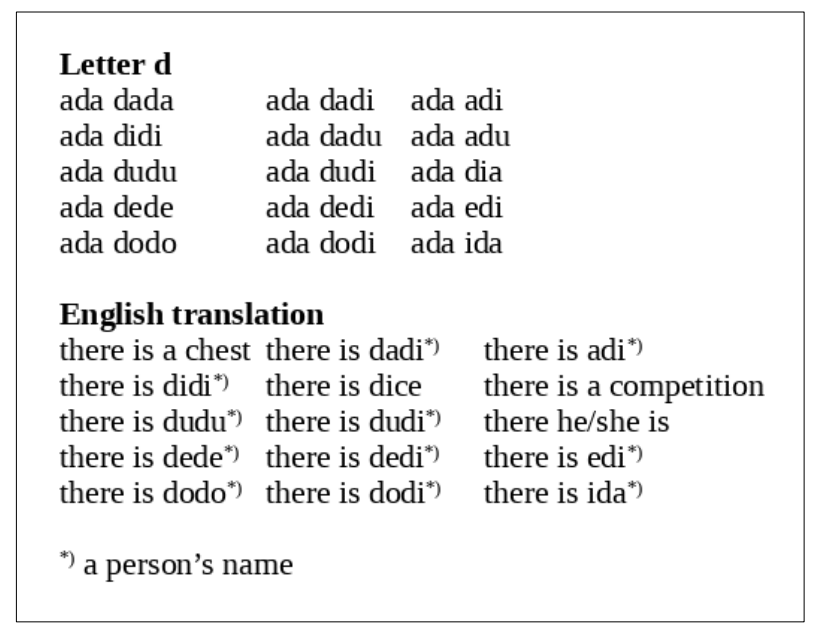

\begin{tabular}{|c|c|c|}
\hline $\begin{array}{l}\text { Letter n } \\
\text { ini nana } \\
\text { ini nini } \\
\text { ini nunu } \\
\text { ini nene } \\
\text { ini nono }\end{array}$ & $\begin{array}{ll}\text { ini nani } & \text { in } \\
\text { ini nina } & \text { in } \\
\text { ini nuni } & \text { in } \\
\text { ini neni } & \text { in } \\
\text { ini noni } & \text { in }\end{array}$ & \\
\hline $\begin{array}{l}\text { English tran } \\
\text { this is nana*) } \\
\text { this is nini*) } \\
\text { this is nunu*) } \\
\text { this is nene*) } \\
\text { this is nono*) }\end{array}$ & $\begin{array}{l}\text { lation } \\
\text { this is nani*) } \\
\text { this is ina*) } \\
\text { this is nuni*) } \\
\text { this is neni*) } \\
\text { this is noni*) }\end{array}$ & $\begin{array}{l}\text { this is ani*) } \\
\text { this is ina*) } \\
\text { this is uni*) } \\
\text { this is eni*) } \\
\text { this is nia*) }\end{array}$ \\
\hline *) a person's & & \\
\hline
\end{tabular}

\begin{tabular}{|c|c|c|}
\hline $\begin{array}{l}\text { Letter t } \\
\text { itu tata } \\
\text { itu titi } \\
\text { itu tutu } \\
\text { itu tete } \\
\text { itu toto }\end{array}$ & $\begin{array}{ll}\text { itu tati } & \text { it } \\
\text { itu tita } & \text { it } \\
\text { itu tuti } & \text { it } \\
\text { itu teti } & \text { it } \\
\text { itu toti } & \text { it }\end{array}$ & $\begin{array}{l}\text { itu ati } \\
\text { itu ita } \\
\text { itu uti } \\
\text { itu eti } \\
\text { itu tia }\end{array}$ \\
\hline \multicolumn{3}{|c|}{$\begin{array}{l}\text { English translation } \\
\text { that is tata*) that is tati*) that is ati*) } \\
\text { that is titi*) } \\
\text { that is tutu* tita*) that is ita*) } \\
\text { that is tuti*) that is uti*) } \\
\text { that is tete*) that is teti*) that is eti*) } \\
\text { that is toto*) that is toti*) that is tia*) }\end{array}$} \\
\hline$\left.{ }^{*}\right)$ a person's & ime & \\
\hline
\end{tabular}

\begin{tabular}{|c|c|c|}
\hline $\begin{array}{l}\text { Letter p } \\
\text { apa ini papa } \\
\text { apa ini pipi } \\
\text { apa ini pupu } \\
\text { apa ini pepe } \\
\text { apa ini popo }\end{array}$ & $\begin{array}{l}\text { apa itu papi } \\
\text { apa itu pipa } \\
\text { apa itu pupi } \\
\text { apa itu pepi } \\
\text { apa itu popi }\end{array}$ & $\begin{array}{l}\text { apa ada api } \\
\text { apa ada ipa } \\
\text { apa ada upi } \\
\text { apa ada epi } \\
\text { apa ada opi }\end{array}$ \\
\hline $\begin{array}{l}\text { English tran } \\
\text { is this papa*) } \\
\text { is this cheek } \\
\text { is this pupu*) } \\
\text { is this pepe*) } \\
\text { is this popo*) }\end{array}$ & $\begin{array}{l}\text { ation } \\
\text { is this papi*) } \\
\text { is this a pipe } \\
\text { is this pupi*) } \\
\text { is this pepi*) } \\
\text { is this popi*) }\end{array}$ & $\begin{array}{l}\text { is this fire } \\
\text { is this ipa*) } \\
\text { is this upi*) } \\
\text { is this epi*) } \\
\text { is this opi*) }\end{array}$ \\
\hline$\left.{ }^{*}\right)$ a person's n & & \\
\hline
\end{tabular}

$\begin{array}{lll}\text { Letter m } & & \\ \text { mana mama } & \text { mana mami } & \text { mana ami } \\ \text { mana mimi } & \text { mana mima } & \text { mana ima } \\ \text { mana mumu } & \text { mana mumi } & \text { mana umi } \\ \text { mana meme } & \text { mana memi } & \text { mana emi } \\ \text { mana momo } & \text { mana momi } & \text { mana mio }\end{array}$

\begin{tabular}{|lll}
\hline Letter c & & \\
ada caca & ada caci & ada aci \\
ini cici & ini cica & ini ica \\
itu cucu & itu cuci & itu uci \\
apa ini cece & apa ini ceci & apa ini eci \\
mana coco & mana oci & mana oca
\end{tabular}

\section{English translation}

where is mama*) where is mimi*)

where is mumu*)

where is meme*)

where is momo*)

*) a person's name where is mami*) where is ami*) where is mima*) where is ima*) where is mumi*) where is umi*) where is memi*) where is emi*) where is momi*) where is mio*)

\section{English translation}

there is caca*)

this is cici*)

that is grandson

is this cece*)

where is coco*)

*) a person's name there is curse this is cica*) that is washing is this ceci*) where is oci*) there is aci*) this is ica*) that is uci*) is this eci*) where is oca*)

Figure 7. Part A, B, C, D, E, and Part F Describing Task Phase 1--6 
The lesson continued until the sixteen phase of initial reading program. The $7^{\text {th }}$ lesson will be letter $\mathrm{j}$.

(1) d, (2) n, (3) t, (4) p, (5) m

(6) c, (7) j, (8) g, (9) y, (10) w

(11) b, (12) h, (13) k, (14) 1

(15) s, (16) r

$* * \mathrm{f}, \mathrm{v}, \mathrm{q}, \mathrm{x}, \mathrm{z}$ (These group of letters was not taught directly)

This test aims to measure students' competence in vocal and 16 consonant letters. Letters 'f', 'v', 'q', 'x', 'z' are not given directly during Initial Reading lesson. Those letters are derived from foreign phonemes, so they might find it difficult to be given at the beginning period. Further, those letters are given as the last material. The example of this foreign phonemes applies to Indonesian words film, foto 'photo', fungsi 'function', visi 'vision', visual, Quran, zakat, ziarah 'pilgrimage'. Some of Indonesian native speakers had difficulties in spelling Arabian phonemes [28].

Students' competence is assessed by steps. If some students cannot complete the steps, teachers may give the incomplete steps at the end of the lesson. When students still find the steps difficult, teachers may help them and may deduct their scores. In some cases, students remain silent, it indicates that those students still cannot read and recognize the letters. Another case happens when students cannot fluently read the word, it may indicate that students are not hesitant with their memory of letters, syllables and words. Teachers help students by asking them mimicking the tasks read by the teachers. In addition, students are considered unfinished or have fewer scores if they cannot fluently read one or more steps.

\subsection{Designing the Learning Process}

Lesson plans for this research were written based on the initial reading objective. The lesson plans employ android photo editor media. The photo editor used is default editor in Samsung Galaxy A20, Galaxy J7 Core and other android phones incidentally. The phone wide screens which around 5 to 6 inches help students to write letters, syllables or words in the initial reading. Meanwhile, for the contents, 'dia tampan' association method is used. By combining phone as media and the method as contents, students found it interesting to learn initial reading. In fact, students of this age like to play with advanced devices.

Furthermore, some learning objectives are developed. The first indicator is the students' interest in the initial reading lesson. It is found that some students are inconvenient with the initial reading lesson. It is difficult for them to remember the letters: one of the reasons they avoid the lesson. By using the devices, it is hoped that students are more interested to learn the initial reading. It helps students to remember the letters, syllables and words. The second indicator is the flexibility and practicality of media. The last indicator is the media effectiveness in minor content in this research. The last indicator is rather important, but it did not measure quantitatively.

\subsection{Developing Learning Process}

The product of this research is a procedure to use Android photo editor as media in the initial reading lesson. The product, then, is validated to experts. The validation is done for the use of the combination of the photo editor and 'dia tampan' method in the initial reading. The validation is done by interviewing four linguists, four primary teachers and developers. Based on the validation resulting from four linguists, it is shown that this teaching aid is somehow applicable. It is stated that the practicality of the usage, the efficient cost in learning and the enjoyability of media create effective learning. Although the result is quite good, some further findings are still developed. Moreover, the same suggestions are stated in the interview result of four lecturers and teachers.

This teaching media has been tested. Limited testing has been done to five students who find the initial reading lesson difficult. Further, it was also applied to 35 students in sequential time. The qualitative data related to validation, procedure, efficiency and effectiveness of this media are discussed further in this article.

Currently, the major revision of the product is not required. Usually, this media is used when students boredom level during learning is increasing or when students find remembering letter difficult. During interviewing, teachers and students also find no urgency to revise the product. While discussion with lecturers, experts, teachers and varsity students are not about revising media but applying the media.

\subsubsection{Students' Competence Description}

In the initial reading task, teachers teach students personally and ask them to read aloud. It is a better idea to make sure the students feel unnoticed being tested, so they may feel more comfortable to perform. From the 16 steps of the initial reading lesson, teachers have to analyze students' competence in every step. The comfortability of students in performing the task is the most important job for the teachers. When teachers find some students cannot recognize the letters, they ask those students to write the letter in photo editor as well as the teachers then, ask the students to read it.

In some of the initial reading tests, the teacher approaches the student to give a initial reading test. Some students do not recognize letters, for example vowels a, i, $u$, e, o. The teacher asks students to write the vowels in the photo editor media. The teacher also writes examples of vowels in the photo editor media and asks students to read the teacher's writing. If students remain silent in several seconds, teachers help them by pronouncing the letter and ask them to mimic the sound. Mimicking the letter is one important technique in Initial Reading Lesson although this technique is not part of scoring. The most common mistake 
the teachers did is letting students repeating their mistakes. As a consequence, students feel frustrated to read. It is against thatthe teachers' role is to create positive learning atmosphere. This circumstance may possibly happen because of unease students-teachers relation. Teachers assume negatively to the incapability of students to read, and students feel that the lesson is too difficult and teachers cannot help them to read.

With the proper teaching technique, students reading ability can be developed properly. the existing media also helps them to understand letters, syllables, words and sentences. For some extents, 'dia tampan' association method considers easier and more applicable for both students and teachers. For dyslectic students, teachers help them by associating the letters to the things surrounding. Like 'c' may be associated with "cincin" (ring) or "cacing" (worm). 'g' for 'gajah' (elephant), and so on. It helps them to recognize letters, to read syllables and words.

Initiate reading and writing lesson using photo editor as the media is considered effective. It is proven by the students' competence development. In the beginning, students were not fluent enough to read due to their memory. In its process, they show positive improvement of their fluency. One of the reasons is teachers consider 'dia tampan' method easy, thus, they can support students to learn comfortably.

\subsubsection{Media Effect}

Students are encouraged to use the media (photo editor) to learn when teachers introduce it to students. They are eager to try to write and join the activity without forcing. For instance, when teachers asked students to write some letters, students willed to write them on the phone, as well as when they are asked to read them. Teachers may vary the activities by asking students to guess the letters. In some cases, if students remain silent, it indicates they fail to memorize the letter. In this part, teachers put their responsibility to help by making an association. For further practice, teachers may dictate the words or syllables to students, and students write them on the phone. The steps must be gradually decreased. They are asked to write words first ('dada' as an example). If they are not able to write it, help them by syllables, if not by letters. Most authors believed that the use of computer/ICT is not appropriate for young children's cognitive, physical, social and emotional development [29]. Nevertheless, that statement does not have decent proof of support. Computer/ICT can be useful media to support young children's learning and development when used appropriately [30]. In addition, developing learning media is considered substantial for universities [31].

The activity of writing on photo editor tends to attract more than writing on the book or board. Students feel less-tired writing on the media compared to writing on the book using pencil or on board using a marker. Another drawback of writing on the board is privacy. Students feel more anxious to walk and write on the board since everyone is watching. This type of anxiety may block students to develop their competence. Therefore, teachers need to help them to give comfort to students while learning. The effectiveness of Android applications (apk) have been researched. Android media influenced greatly to deliver chemistry material to high school students [32]. There was also a study investigated the smartphone feature and application to Reading Learning Strategies (RLS) [33]. Furthermore, in 21st century learning, Digital Game-Based Learning (DGBL) may be utilized and developed [34].

Students' interest in the lesson is seen explicitly. Because of that, teachers need to maintain these students' interest and enthusiasm until they are able to finish Initial Reading Lesson. This interest was observed from the students' activities during Initial Reading Lesson. As proofs, none of students refused to write when the teachers asked them. However, in some cases, some students need clue or guidance from the teachers when they found it difficult or could not memorize the letter. In addition, students' interest could also be seen from their curiosity to what teachers were doing. It seemed that they wanted to try and join the activities. In this part, teachers have to show their attention and reward to students' motivation. Teachers also need to join the students' activities as long as it is relevant to the lesson.

Another possible activity to apply is by connecting the phone used to the projector, so students' writing result can be seen by all their friends. Nevertheless, this activity has an advantage and drawback. Advanced students may feel bored because they have already read it several times. Besides, their friends may not appreciate the writing because of wrong spelling or bad writing.

\subsubsection{Cloud Image Result from Interviewing Teachers and Media Experts}

The interview was done to 11 teachers and 5 learning media experts to find out their responses toward the Android photo editor as learning media. The result was collected, classified, translated and analyzed by using Word Cloud from Orange Data Mining version 3.24.1.

Teachers were asked to write their comment toward the Android photo editor as learning media. The total analysed words are 111 and the result is as follows (Figure 8).

The word "media" appears 17 times $(15.32 \%)$. The word "learning" appears 16 times (14.41\%). The word "technology" appears 9 times $(8.11 \%)$. The word "gadget, useful, student" appears 7 times each $(6.31 \%)$. The word "good, interesting, use" appears 6 times each (5.41\%). The word "initial, reading" appears 5 times each $(4.50 \%)$. The word "read, video" appears 4 times each $(3.60 \%)$. The word "easy" appears 3 times $(2.70 \%)$. While the words "find, schools, accompany, parents, home, must, using, easily, one teacher, still, applied, process, inspiring" 
appears twice each $(1.80 \%)$, and the rests appear once each $(0.90 \%)$.

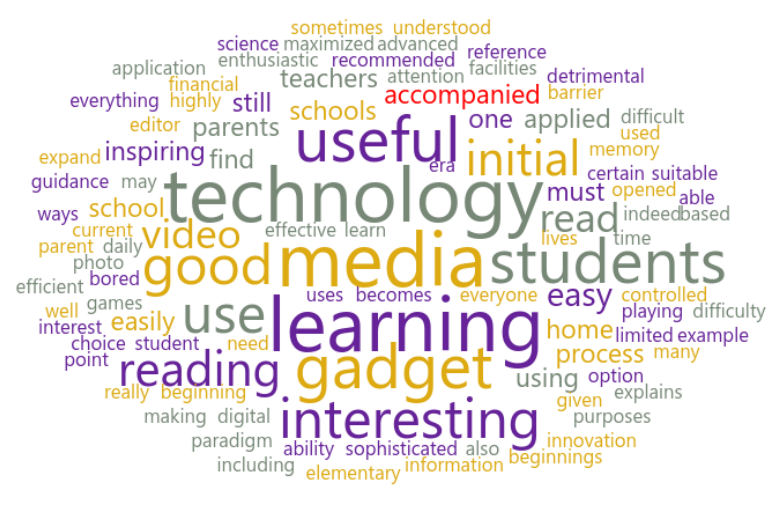

Figure 8. Cloud Image from Interviewing Teachers

The second interview was done to 5 learning media experts toward the Android photo editor. They are required to write their comments related to it. Using Word Cloud image, the total analysed words are 67 , and the distribution is as follow (Figure 9).

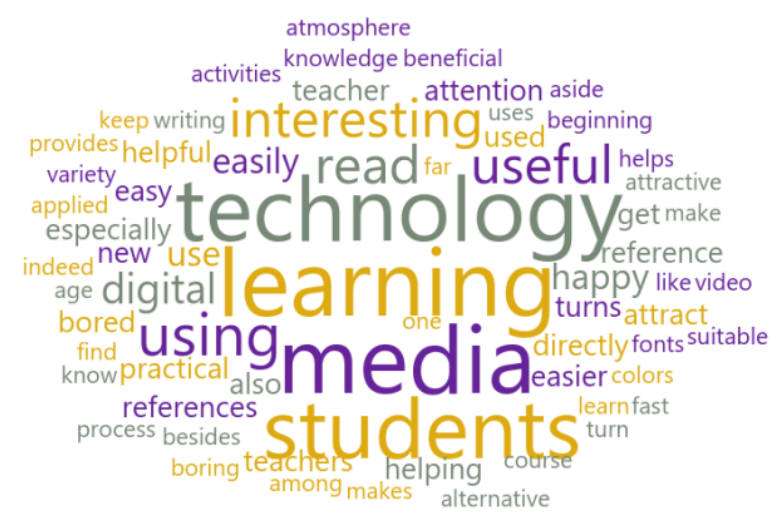

Figure 9. Cloud Image from Interviewing Media Expert

The word "learning" appears 21 times (31.34\%). The word "media" appears 13 times (19.40\%). The word "technology" appears 12 times (17.91\%). The word "student" appears 11 times (16.42\%). The word "using" appears 7 times (10.45\%). The word "read, interesting, useful" appears 6 times each (8.96\%). The word "digital" appears 4 times (5.97\%). The word "use, easily, happy" appears 3 times each $(4.48 \%)$. While the rests appear only twice and once.

\subsubsection{Refreshing and Learning Time Span}

In the initial reading lesson, refreshing is considered important. Students who have spent too much time learning have to rest for a while. Teachers may ask them to do small talk, play with them and so on. Let them smile and laugh before continuing the lesson. As for the information, there is no specific time span for students to learn to read.
Students who are able to read fluently tend to have more time span to read and vice versa. The most effective time to learn is about 1.5 hours a day. It is better to finish the Initial Reading Lesson gradually, step by step. By remembering a new letter every day without forgetting the previous letters using 'dia tampan' Initial Reading Lesson, 16 times of lesson are possible to finish it with guidance.

\section{Conclusions}

In sum, there are three things in Initial Reading Lesson in this research: (1) steps to use photo editor as a media; (2) students' response toward the media; (3) students' competence in Initial Reading Lesson. First, in the steps in using photo editor as a media, teachers capture a completely black picture as a board on the phone. By using doodle, students and teachers are asked to do various acts of reading and writing. Second, students' enthusiasm to use photo editor as media. This media can be manipulated by both teachers and students directly. As a result, students show their interest to join the lesson and try the media. They will also do some tasks given by the teachers joyfully. Without using pencil and paper, students write a lot unnoticed with unlimited board. Finally, students' competence in Initial Reading Lesson is as follow. Association media helps students to remember letters, syllables and sentences. Further, students' memory can be tested by writing the letters, syllables and sentences on the photo editor. Combined with 'dia tampan' methods, students' anxiety can be seen clearly. This method also helps students to develop their competence to finish Initial Reading Lesson.

\section{Acknowledgements}

The best regard is given to all headmasters of schools, teachers, and students as part of this research. We also thank Direktorat Riset dan Pengabdian Masyarakat. Direktorat Jenderal Penguatan Riset dan Pengembangan, Kementerian Riset, Teknologi, dan Pendidikan Tinggi for financial support of the 2019 research grant.

\section{REFERENCES}

[1] A. Roohani, A. Jafarpour, and S. Zarei, "Effects of Visualisation and Advance Organisers in Reading Multimedia-Based Texts," 3L: Language, Linguistics, Literature ${ }^{\circledR}$, vol. 21, no. 2, Jun. 2015, [Online]. Available: http://ejournals.ukm.my/31/article/view/8233.

[2] A. Rouhi and H. Mohebbi, "Glosses, Spatial Intelligence, and L2 Vocabulary Learning in Multimedia Context," $3 L$ : Language, Linguistics, Literature ${ }^{\circledR}$, vol. 19, no. 2, Jun. 2013, [Online]. Available:http://ejournals.ukm.my/31/artic 
le/view/2237.

[3] C. Gabarre, S. Gabarre, R. Din, P. Mohd Shah, and A. Abdul Karim, "iPads in the foreign language classroom: A learner's perspective," $3 L$ : The Southeast Asian Journal of English Language Studies, vol. 20, no. 01, pp. 115-128, Mar. 2014, doi: 10.17576/3L-2014-2001-09.

[4] C.-C. Tsai and C. Chou, "Diagnosing students' alternative conceptions in science," Journal of Computer Assisted Learning, vol. 18, no. 2, pp. 157-165, 2002, doi: 10.1046/j.0266-4909.2002.00223.x.

[5] N. M. Noor, H. Azman, N. F. M. Nor, A. Hamat, and N. A. Bakar, "Development and Evaluation of the Interactive English Language Literacy System (i-ELLS) for online reading comprehension," $3 L$ : Language, Linguistics, Literature $\AA$, vol. 17, no. 0, 2011, [Online]. Available: http://ejournals.ukm.my/31/article/view/985.

[6] Sun-Young Kim and Jiwon Paek, "The role of online written communication channels for reading-writing connection,' Linguistic Research, vol. 36, no. 3, pp. 81-105, 2019, doi: 10.17250/khisli.36..201909.004.

[7] N. F. M. Nor, H. Azman, and A. Hamat, "Investigating Students' Use of Online Annotation Tool in an Online Reading Environment," 3L: Language, Linguistics, Literature ${ }^{\circledR}$, vol. 19, no. 3, Sep. 2013, [Online]. Available: http://ejournals.ukm.my/31/article/view/3655/2301.

[8] Y. Liu and X. Gu, "Media multitasking, attention, and comprehension: a deep investigation into fragmented reading," Educational Technology Research and Development, pp. 1-21, Apr. 2019, doi: 10.1007/s11423-019-09667-2.

[9] [9] G. Awada and M. G.-C. Plana, "Multiple Strategies Approach and EFL Reading Comprehension of Learners with Dyslexia: Teachers' Perceptions," INT J INSTRUCTION, vol. 11, no. 3, pp. 463-476, Jul. 2018, doi: 10.12973/iji.2018.11332a.

[10] P. D. Iswara, "Membaca Strategi dia tampan," 2009. http://iswara.staf.upi.edu/2009/04/28/membaca-strategi-dia -tampan/ (accessed Oct. 18, 2019).

[11] Pranabadrun, Pembelajaran membaca permulaan dengan strategi dia tampan.wmv - YouTube. 2010.

[12] P. D. Iswara, Surat Pencatatan Ciptaan, Sistem Membaca Permulaan dengan Asosiasi dan dia tampan, Nomor Permohonan C00201600458, Nomor Pencatatan 078346, Hak Kekayaan Intelektual (HKI). 2016.

[13] L. Vernon-Feagans, K. Kainz, S. Amendum, M. Ginsberg, T. Wood, and A. Bock, "Targeted Reading Intervention," Learning Disability Quarterly, vol. 35, no. 2, pp. 102-114, 2012, doi: $10.1177 / 0731948711434048$.

[14] V. S. Damaianti, "Volitional Strategies Through Metacognitive Development In Fostering Reading Motivation," Indonesian Journal of Applied Linguistics, vol. 7, no. 2, p. 36, Sep. 2017, doi: 10.17509/ijal.v7i2.8130.

[15] P. L. Morgan, D. Fuchs, D. L. Compton, D. S. Cordray, and L. S. Fuchs, "Does Early Reading Failure Decrease Children's Reading Motivation?" Journal of Learning Disabilities, vol. 41, no. 5, pp. 387-404, 2008.

[16] V. J. Molfese, D. L. Molfese, A. T. Modglin, J. Walker, and J.
Neamon, Screening early reading skills in preschool children: Get Ready to Read., vol. 22. 2004.

[17] N. H. Clemens, E. S. Shapiro, J.-Y. Wu, A. B. Taylor, and G. L. Caskie, "Monitoring Early First-Grade Reading Progress: A Comparison of Two Measures," Journal of Learning Disabilities, vol. 47, no. 3, pp. 254-270, 2014, doi: $10.1177 / 0022219412454455$.

[18] E. A. Swanson et al., "A Synthesis of Read-Aloud Interventions on Early Reading Outcomes Among Preschool through Third Graders at Risk for Reading Difficulties," Journal of Learning Disabilities, vol. 44, no. 3, pp. 258-275, 2011, doi: 10.1177/0022219410378444.A.

[19] A. B. Kurniawati, "Hubungan Kondisi Keaksaraan Keluarga dan Motivasi Membaca dengan Kemampuan Membaca Permulaan," Jurnal Pendidikan Usia Dini, vol. 7, no. 1, pp. 1-16, Apr. 2013.

[20] S. A. Petrill, K. Deater-Deckard, L. A. Thompson, L. S. DeThorne, Schatschneider, and Christopher, "Reading Skills in Early Readers," Journal of Learning Disabilities, vol. 39, no. 1, pp. 48-55, 2006.

[21] T. A. Kouri, "Comparison of Feedback Strategies During Guided Reading Instruction with Children with Language Impairment," Contemporary Issues in Communication Science and Disorders, vol. 43, pp. 268-284, 2016.

[22] I.-F. Liu and H.-W. Ko, "Online Reading Research: A Selective Review," Journal of Research in Education Sciences, vol. 62, no. 2, pp. 61-88, 2017, doi: 10.6209/JORIES.2017.62(2).03.

[23] R. Setiyadi, U. Kuswendi, M. G. Ristiana, and M. G. Ristiana, "Learning of Reading Comprehension through Reading Workshop in the Industry 4.0," Mimbar Sekolah Dasar, vol. 6, no. 2, p. 160, Jul. 2019, doi: 10.17509/mimbar-sd.v6i2.17397.

[24] Thiagarajan, Sivasailam, D. Semmel, and M. I. Semmel, "Instructional Development for Training Teachers of Exception Children." Indiana Univ., Bloomington. Center for Innovation inTeaching the Handicapped, 1974, [Online]. Available: https://files.eric.ed.gov/fulltext/ED090725.pdf.

[25] P. D. Iswara, J. Julia, and T. Supriyadi, "A survey on language learning through song-based information technology," IOP Conference Series: Materials Science and Engineering, vol. 434, no. 1, p. 012069, Dec. 2018, doi: 10.1088/1757-899X/434/1/012069.

[26] P. D. Iswara, S. Gunara, and Julia, “Students' acceptance of song lyrics containing national characters," in Global Conference on Teaching, Assessment, and Learning in Education (GC-TALE 2017), Denpasar, Bali, Indonesia, 2018, vol. 00096, pp. doi:https://doi.org/10.1051/shsconf/20184200096.

[27] N. S. Anderson, "Word associations to individual letters," Journal of Verbal Learning and Verbal Behavior, vol. 4, no. 6, pp. 541-545, Dec. 1965, doi: 10.1016/S0022-5371(65)80055-X.

[28] T. Supriyadi, J. Julia, and P. D. Iswara, "Phonological Interference in Reciting Al-Qur'an: A Critical Reflection on the Learning of Al-Qur'an Phonology through Action Research," International Journal of Learning, Teaching and Educational Research, vol. 18, no. 9, pp. 46-77, Sep. 
2019, doi: 10.26803/ijlter.18.9.3.

[29] M. Gjelaj, K. Buza, K. Shatri, and N. Zabeli, "Digital Technologies in Early Childhood: Attitudes and Practices of Parents and Teachers in Kosovo," INT J INSTRUCTION, vol. 13, no. 1, pp. 165-184, Jan. 2020, doi:10.29333/iji.2020.13111a.

[30] R. Bolstad, "The role and potential of ICT in early childhood education: A review of New Zealand and international literature." New Zealand Council for Educational Research, 2004, Accessed: Jan. 07, 2020. [Online]. Available: https://www.nzcer.org.nz/system/files/ictinecefi nal.pdf.

[31] A. A. Cherkashina, Y. I. Tyazhlov, V. Yu. Merinov, E. V. Khovanova, S. V. Ushakova, and M. V. Korotitskaya, "University as a Medium of Promoting Media Literacy among Schoolchildren," ujer, vol. 7, no. 10B, pp. 58-62, Oct. 2019, doi: 10.13189/ujer.2019.071812.

[32] A. D. Astiningsih and C. F. Partana, "Using Android Media for Chemistry Learning Construction of Motivation and Metacognition Ability," INT J INSTRUCTION, vol. 13, no. 1, pp. 279-294, Jan. 2020, doi: 10.29333/iji.2020.13119a.

[33] A. A. F. Alzubi, M. K. A. M. Singh, and A. N. Hazaea, "Investigating Reading Learning Strategies through Smartphones on Saudi Learners' Psychological Autonomy in Reading Context," INT J INSTRUCTION, vol. 12, no. 2, pp. 99-114, Apr. 2019, doi: 10.29333/iji.2019.1227a.

[34] L. Farhana Md Ibharim, M. Hayati Mohamad Yatim, and N. Zuhaidah Mohamed Zain, "Development of Rubric to Measure Children's $21^{\text {st }}$ Century Skills in Digital Game-Based Learning," ujer, vol. 7, no. 10A, pp. 7-12, Oct. 2019, doi: 10.13189/ujer.2019.071702. 